\section{REFERRALS IN GENERAL PRACTICE} BY

\author{
PHILIP HOPKINS, M.R.C.S., L.R.C.P. \\ General Practitioner, London
}

The primary objects of the investigation described in this paper were two in number: (1) to examine the reasons for which patients may be referred by a general practitioner to his consultant and specialist colleagues; and (2) to discover what functions are most required by the patient and his doctor from the hospital service.

Analysis of the results has not only answered these questions, it has also provided further evidence of the high incidence of psychoneurosis and stress disorders. This study was based on a single practice.

\section{The Practice}

The practice is centred on a part of London where all social classes are represented. A near-by colleague and I deputize for each other for one half-day each week, alternate week-ends, and holidays, and with this arrangement it is a simple matter to keep complete records.

There is a fairly large turnover of patients, as people are constantly moving into and out of this district, and this may account for the high percentage of the practice population seen each year. A number of temporary residents are included in the study.

Table I shows the size of my National Health Service list for the three years 1951, 1952, and 1953, and Table II shows the number of patients entering and leaving the practice during this time. I estimate that some $85 \%$ of the practice population consult me each year.

TABLE I.-Number of Patients on National Health Service List, and Temporary Residents for 1951-3

\begin{tabular}{|c|c|c|c|c|c|c|c|}
\hline \multirow{2}{*}{\multicolumn{2}{|c|}{$\begin{array}{l}\text { For Quarter } \\
\text { Ending: }\end{array}$}} & \multicolumn{2}{|c|}{1951} & \multicolumn{2}{|c|}{1952} & \multicolumn{2}{|c|}{1953} \\
\hline & & $\begin{array}{l}\text { On } \\
\text { List }\end{array}$ & $\begin{array}{l}\text { Temp. } \\
\text { Res. }\end{array}$ & $\begin{array}{l}\text { On } \\
\text { List }\end{array}$ & $\begin{array}{l}\text { Temp. } \\
\text { Res. }\end{array}$ & $\begin{array}{l}\text { On } \\
\text { List }\end{array}$ & $\begin{array}{l}\text { Temp. } \\
\text { Res. }\end{array}$ \\
\hline $\begin{array}{l}\text { Mar. } 31 \\
\text { une } 30 \\
\text { ept. } 30 \\
\text { Pec. } 31\end{array}$ & $\begin{array}{l}. \\
. .\end{array}$ & $\begin{array}{l}1,217 \\
1,265 \\
1,272 \\
1,272\end{array}$ & $\begin{array}{l}18 \\
15 \\
11 \\
15\end{array}$ & $\begin{array}{l}1,339 \\
1,355 \\
1,341 \\
1,386\end{array}$ & $\begin{array}{l}19 \\
18 \\
17 \\
11\end{array}$ & $\begin{array}{l}1,409 \\
1,425 \\
1,486 \\
1,515\end{array}$ & $\begin{array}{l}19 \\
11 \\
19 \\
12\end{array}$ \\
\hline
\end{tabular}

Average No. of patients " at risk" each year $=1,370-1,355$ on list and 15 temporary residents.

TABLE II.-Number of Patients Joining and Leaving List in 1951-3

\begin{tabular}{|c|c|c|c|}
\hline & 1951 & 1952 & 1953 \\
\hline $\begin{array}{l}\text { Joining list } \\
\text { Leaving list }\end{array}$ & $\begin{array}{l}376 \\
250\end{array}$ & $\begin{array}{l}430 \\
314\end{array}$ & $\begin{array}{l}401 \\
272\end{array}$ \\
\hline
\end{tabular}

In an analysis of the clinical records of eight practices during the period April, 1951, to March, 1952, Logan (1953) found the number of consultations per 100 practice population to vary from 287 in a rural practice to 468.9 in a "lower working-class neighbourhood."

If this method of expressing the rate of consultations is used in my practice it works out at 321 consultations per 100 practice population. In Logan's survey the two practices with rates per 100 nearest mine were in North-east London (338.8) and in " a better working-class practice in Norwich" (331).

The number of consultations in my practice made during the years 1951-3 is shown for each year and place of

TABLE III.-Number and Place of Consultations for each Year

\begin{tabular}{|c|c|c|c|c|c|}
\hline Consultation & 1951 & 1952 & 1953 & Total & $\%$ \\
\hline $\begin{array}{l}\text { In surgery } \\
\text { On visit }\end{array}$ & $\begin{array}{r}3,125 \\
919\end{array}$ & $\begin{array}{l}3,328 \\
1,021\end{array}$ & $\begin{array}{l}3,648 \\
1,167\end{array}$ & $\begin{array}{r}10,101 \\
3,107\end{array}$ & $\begin{array}{l}76 \cdot 5 \\
23 \cdot 5\end{array}$ \\
\hline Total & 4,044 & 4,349 & 4,815 & 13,208 & 100 \\
\hline
\end{tabular}

consultation in Table III. It is interesting to note that the average number of consultations per 100 practice population per annum for the three years is 330 .

Logan found that for all eight practices in his survey the average attendance rate at the doctor's surgery was $68 \%$. From these figures it would seem reasonable to say that the behaviour of my patients is very similar to that in the practices which formed the basis for Logan's survey. It is certainly true that the general incidence of illnesses classified in the usual groups is much the same in my practice as in others that have been recorded and published.

\section{The Investigation}

My daybook contains a record of all patients seen, and the material for this investigation was obtained from this source.

By "referral" I mean that a patient was referred to a consultant or specialist at a hospital or clinic, or in a small number of instances by private arrangement between the patient and the consultant. In all cases, however, the patients were registered with me under the National Health Service. A patient seen by a consultant with me at a domiciliary visit is also here accepted as a referral. Patients referred to a casualty department of a hospital are also included under this term.

Throughout this paper the figures given (unless otherwise stated) are for referrals and do not indicate actual patients. All such referrals during the three years 1951-3 were determined from the daybook, and total 1,225. Table IV shows their distribution as in-patients, out-patients (including those referred to casualty departments), and those seen on domiciliary visits; the figures are given separately for medical and surgical conditions.

TABLe IV.-Analysis of 1,225 Referrals, According to Sex, as In- and Out-patients, and Domiciliary Consultations, for Medical and Surgical Conditions during 1951-3

\begin{tabular}{|c|c|c|c|c|c|c|c|c|}
\hline & \multicolumn{3}{|c|}{$\begin{array}{l}\text { No. of Referrals for } \\
\text { Medical Conditions }\end{array}$} & \multicolumn{3}{|c|}{$\begin{array}{l}\text { No. of Referrals for } \\
\text { Surgical Conditions }\end{array}$} & \multirow{2}{*}{ Total } & \multirow{2}{*}{$\%$} \\
\hline & $\begin{array}{c}\text { In- } \\
\text { patient }\end{array}$ & $\begin{array}{c}\text { Out- } \\
\text { patient }\end{array}$ & $\begin{array}{l}\text { Dom. } \\
\text { Consn }\end{array}$ & $\begin{array}{c}\text { In- } \\
\text { patient }\end{array}$ & $\begin{array}{c}\text { Out- } \\
\text { patient }\end{array}$ & $\begin{array}{l}\text { Dom. } \\
\text { Consn }\end{array}$ & & \\
\hline $\begin{array}{l}\text { Male.. } \\
\text { Female }\end{array}$ & $\begin{array}{l}30 \\
31\end{array}$ & $\begin{array}{l}173 \\
207\end{array}$ & $\begin{array}{l}17 \\
29\end{array}$ & $\begin{array}{l}31 \\
24\end{array}$ & $\begin{array}{l}267 \\
382\end{array}$ & $\begin{array}{l}14 \\
20\end{array}$ & $\begin{array}{l}532 \\
693\end{array}$ & $\begin{array}{l}43.4 \\
56.6 \\
\end{array}$ \\
\hline \multirow[t]{2}{*}{ Total } & 61 & 380 & 46 & 55 & 649 & 34 & \multirow[t]{2}{*}{1,225} & \multirow[t]{2}{*}{100} \\
\hline & \multicolumn{3}{|c|}{487} & \multicolumn{3}{|c|}{738} & & \\
\hline
\end{tabular}

Table V.-Distribution of 860 Patients According to Sex and Age Group

\begin{tabular}{|c|c|c|c|c|c|c|}
\hline Sex & $0-14$ & $15-44$ & 45-64 & $65+$ & All Ages & $\%$ \\
\hline Male $\begin{cases}\text { No. } & . . \\
\% & \ldots\end{cases}$ & $\begin{array}{l}53 \\
13 \cdot 7\end{array}$ & $\begin{array}{c}227 \\
58.9\end{array}$ & $\begin{array}{l}63 \\
16.5\end{array}$ & $\begin{array}{l}42 \\
10.9\end{array}$ & 385 & 44.8 \\
\hline Female $\left\{\begin{array}{ll}\text { No. } \\
\%\end{array} \quad \ldots\right.$ & $\begin{array}{l}58 \\
12 \cdot 3\end{array}$ & $\begin{array}{l}248 \\
52 \cdot 1\end{array}$ & $\begin{array}{l}112 \\
23.4\end{array}$ & $\begin{array}{l}57 \\
12 \cdot 2\end{array}$ & 475 & $55 \cdot 2$ \\
\hline Total $\begin{cases}\text { No. } & . . \\
\% & . .\end{cases}$ & ${ }_{12.8}^{111}$ & $\begin{array}{l}475 \\
55.2\end{array}$ & $\begin{array}{l}175 \\
20 \cdot 3\end{array}$ & $\begin{array}{l}99 \\
11.7\end{array}$ & 860 & 100 \\
\hline
\end{tabular}

TABle VI.-Percentage Distribution of Practice Population According to Sex and Age Group, as Calculated in June. 1955

\begin{tabular}{cc|c|c|c|c|c}
\hline \multicolumn{2}{c|}{ Sex } & $0-14$ & $15-44$ & $45-64$ & $65+$ & All Ages \\
\hline Male &.. & 10.6 & 59.7 & 20.8 & 8.9 & 46.1 \\
Female & $\ldots$ & 12.9 & 50.1 & 24.4 & 12.6 & 53.9 \\
\hline Total &.. & 11.8 & 54.7 & 22.7 & 10.8 & 100 \\
\hline
\end{tabular}

During the three years under review the actual number of patients referred was 860 . Their distribution according to sex and age group is shown in Table V. The percentage incidence of patients according to sex and age group in the practice population was recently calculated in preparation for participation in the Morbidity Survey which is being conducted by the College of General Practitioners (1955) in collaboration with the Registrar-General's Department. The findings are shown in Table VI. Comparison of these 
figures shows a fairly even distribution of all age groups among the referrals, there being only a slight relative reduction in the number of males in age group 45-64, with a slight increase in the males in age group $65+$ referred.

The large majority of these 860 patients referred attended hospital only once or twice each; only a small number were referred three or more times each. The figures are shown in Table VII.

TABLE VII.-Number of Patients Referred One to Six Times each

\begin{tabular}{|c|c|c|c|c|}
\hline \multicolumn{3}{|c|}{ No. of Patients } & \multirow{2}{*}{$\begin{array}{c}\text { Times Each } \\
\text { was } \\
\text { Referred }\end{array}$} & \multirow{2}{*}{$\begin{array}{c}\text { Total No. } \\
\text { of } \\
\text { Referrals }\end{array}$} \\
\hline Male & Female & Total & & \\
\hline $\begin{array}{r}292 \\
60 \\
23 \\
8 \\
1 \\
1\end{array}$ & $\begin{array}{r}328 \\
96 \\
34 \\
9 \\
5 \\
3\end{array}$ & $\begin{array}{r}620 \\
156 \\
57 \\
17 \\
6 \\
4\end{array}$ & $\begin{array}{l}1 \\
2 \\
3 \\
4 \\
5 \\
6\end{array}$ & $\begin{array}{r}620 \\
312 \\
171 \\
68 \\
30 \\
24\end{array}$ \\
\hline 385 & 475 & 860 & & 1,225 \\
\hline
\end{tabular}

In the medical literature available to me I have been able to find very little reference to the subject of referrals from general practice, and even this has been confined only to actual statistics.

Pemberton (1949) published a survey of illness occurring in eight practices in Sheffield. He reported that $2 \%$ of the 4,656 consultations resulted in referral to a hospital outpatient department, in $0.16 \%$ to an in-patient department, and in $0.2 \%$ to a local authority clinic.

Fry (1952) described the work in his practice for the year 1951. Of the 4,456 patients on his list he referred 307 for consultant's opinion (6.9\% of practice); 240 for radiological investigation $(5.4 \%$ of practice) ; and 220 for pathological investigation ( $4.9 \%$ of practice). No mention is made of patients referred to hospital for treatment.

Logan (1954) summarized his findings in a survey of the work of eight practices during the year April 1, 1951, to March 31, 1952, and he gives a detailed statistical analysis of the numbers of patients referred to hospitals as in- and out-patients, and also of those seen on domiciliary consultations and by private arrangement. He reported that twothirds of the total lists of the eight practices were seen. In all, 19,000 patients were seen for 105,000 consultations. Over 4,300 referrals were recorded, an average of 15.8 per 100 patients on the combined lists or 4.1 per 100 consultations given. Logan comments on the "startling differences" between the referral rates in the eight practicesthe rate ranged from 32.1 per 100 patients in Polegate to 6.4 in Walthamstow. There is no indication, however, of the types of cases referred or the reasons for their referral.

\section{Referral for Treatment}

Examination of the reasons for referring patients is more revealing than a simple statistical analysis. It is fully appreciated that individual practitioners may vary widely in their approach to their patients and in their methods of treatment, but it is more than likely that there may be factors common to all. The commonest reason for referral of patients during the three years 1951-3 was for some form of treatment requiring a special technique, and of the 1,225 referrals under discussion $660(53.8 \%)$ were for treatment. Some had already been investigated in order to confirm a provisional diagnosis before referral, or to exclude possible underlying physical disease before referral for psychiatric treatment. Very often the actual treatment is decided by the general practitioner when he chooses the specialist to see a particular patient

Analysis of the 660 referrals for treatment is shown in Table VIII. Out-patient referrals are more numerous than in-patient referrals; for referrals to physicians the ratio out-patient: in-patient is approximately $2: 1$. As might be expected, in the case of surgical referrals the ratio of outpatient : in-patient is nearly $5: 1$. The proportion of females:
TABLE VIII.-Analysis of 660 Referrals for Treatment

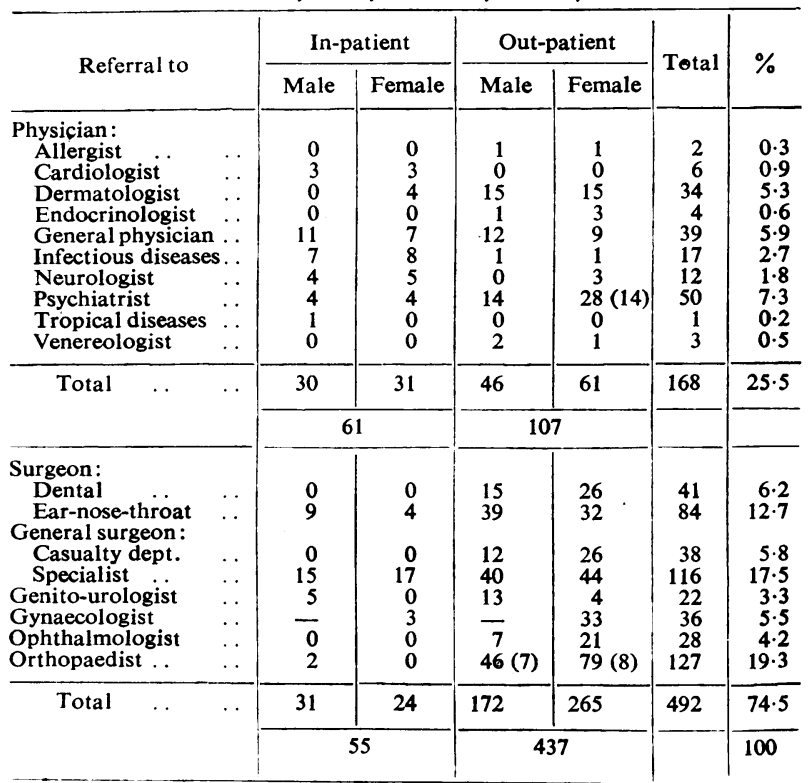

Figures in parentheses denote number seen on domiciliary consultation.

males is practically $1: 1$ for medical referrals, and nearly $2: 1$ for surgical referrals, where the referral is for treatment.

The commonest cause for admission for in-patient treatment is acute appendicitis (10 female and 6 male), and a further 11 female and 6 male referrals were made to surgical out-patient departments for consideration for interval appendicectomy where there had been recurrent appendicitis.

The largest number of referrals for medical treatment were psychiatric, and consisted mainly of cases of severe psychoneurosis and of psychosis (see Table XIII).

The next two largest groups referred for medical treatment were for general medical conditions (including chest affections) and dermatological complaints. The latter referrals included most of those patients who were referred to specialists in response to their own request-a valid reason for referral in those illnesses known to be chronic and difficult to treat successfully.

Among the surgical referrals for treatment the largest group were for orthopaedic conditions, although many of them could have been referred direct to a department of physical medicine for the required physiotherapy had this been available. Fortunately there has been a change since this survey was completed, and patients may now be referred direct for physiotherapy in this district.

It is perhaps surprising how many patients consult their doctor when they require dental attention, although they often present with acute submandibular adenitis and require the combined attention of dental surgeon and doctor.

\section{Referral for Special Investigation}

The second most common reason for referral was for special investigations in order to confirm a provisional clinical diagnosis, or in many cases to exclude possible underlying physical disease when the diagnosis was a psychoneurosis. Often the real reason for this latter type of referral is one's own anxiety-it is so often said that "organic disease" may be missed if patients are "labelled" neurotic, and as this is one of the most common diagnoses it is hardly surprising that it becomes necessary " to make sure" nothing is being overlooked.

There is no doubt that the standard of general practice will be improved only by allowing the family doctor full facilities for properly investigating his patients in order to reach an accurate diagnosis. It is only by this means that adequate treatmer.t may be started. This means there must be open access to pathological laboratories and radiological depart- 
ments, and although some hospitals have shown their willingness to co-operate with the general practitioner there are many that have not. The argument usually put forward is that there is not the room or the staff to deal with the extra work involved. This is nonsense, as shown by this investigation. Table IX shows the number of referrals for pathological investigations, and Table $X$ shows the number of referrals for radiological investigation. In both cases the majority had first to be referred to a consultative outpatient department.

TABLE IX.-Number of Referrals for Pathological Investigations

\begin{tabular}{rr|c|c|c}
\hline & & Male & Female & Total \\
\hline \begin{tabular}{rr|c|} 
Surgical condition \\
Medical
\end{tabular} ". &.. & 12 & 14 & 26 \\
\hline Total &.. & 50 & 66 & 104 \\
\hline
\end{tabular}

TABLE X.-Analysis of 252 Referrals for Radiological Investigation. According to Sex and Type of $X$-ray Examination Requested

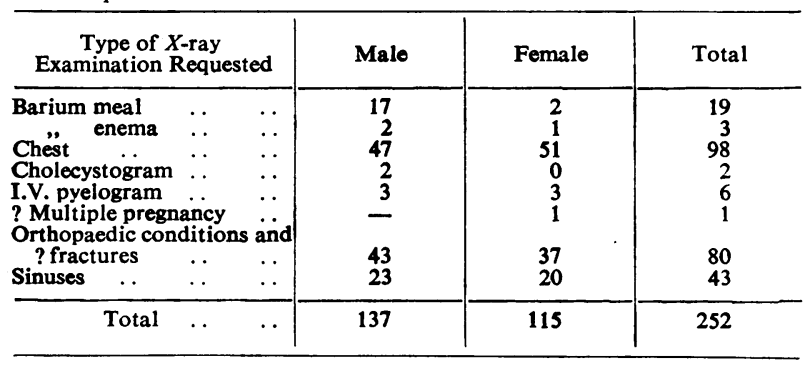

Hunt (1951) described a diagnostic unit he had built in the first five years after the war, and his discussion of the work carried out during that time shows the high standard of practice made possible by having available the facilities for pathological and $x$-ray investigations. This unit was outside the National Health Service, but its excellence should be the aim of the general practitioner within the National Health Service. During the years 1948, 1949, and 19507,020 pathological investigations were carried out, and 1,476 sets of $x$-ray films taken. Hunt had consultants in pathology and radiology to advise him. The number of patients seen in the three years is not stated, but in five years 3,864 patients were treated. This implies a high incidence of investigations per patient, but the standard of practice was such that he wrote : "This unit has enabled work to be done in general practice which would have been very difficult without these facilities."

Since the present survey was completed one hospital in the area in which $I$ practise has opened its pathological and $x$-ray departments to general practitioners ; my referral rate to consultative out-patient departments has dropped because of this, as might be expected from the results of this study. There are other hospitals, however, also serving this area, whose pathological and $x$-ray departments are still closed to general practitioners, so that there is a tendency to overburden the special departments of the hospital with open access. Clearly it is necessary for all hospitals to play their part in co-operating with the general practitioner-and the teaching hospitals should lead the way.

\section{Referral for Consultant's Opinion}

During the three years under review out of the 1.225 referrals only 183 were for a consultant's opinion about the diagnosis or for advice and guidance with regard to further management of the patient. An analysis of these 183 referrals is shown in Table XI.

These figures show almost equal numbers of surgical and medical referrals, but with a ratio of nearly $2: 1$ of females: males.

It will be noticed that nearly one-third of these referrals for an opinion took place on domiciliary consultation-a
TABLE XI.-Analysis of 183 Referrals for Opinion

\begin{tabular}{|c|c|c|c|c|c|c|c|}
\hline \multirow{2}{*}{\multicolumn{2}{|c|}{$\begin{array}{c}\text { Referred } \\
\text { to }\end{array}$}} & \multicolumn{2}{|c|}{ Male } & \multicolumn{2}{|c|}{ Female } & \multirow{2}{*}{ Total } & \multirow[b]{2}{*}{$\%$} \\
\hline & & $\underset{\text { patient }}{\text { Out- }}$ & $\begin{array}{l}\text { Dom. } \\
\text { Consn. }\end{array}$ & $\underset{\text { patient }}{\text { Out- }}$ & $\begin{array}{l}\text { Dom. } \\
\text { Consn. }\end{array}$ & & \\
\hline $\begin{array}{l}\text { Physician: } \\
\text { Allergist } \\
\text { Cardiologist } \\
\text { Dermatologist } \\
\text { Endocrinologist } \\
\text { General physician } \\
\text { Geriatrician } \\
\text { Infectious diseases } \\
\text { Neurologist } \\
\text { Paediatrician } \\
\text { Psychiatrist... } \\
\text { Tropical diseases } \\
\text { Venereologist }\end{array}$ & $\begin{array}{l}\ldots \\
\cdots \\
\cdots \\
\ldots \\
\cdots \\
\cdots \\
\cdots \\
\cdots\end{array}$ & $\begin{array}{l}1 \\
6 \\
1 \\
2 \\
4 \\
0 \\
0 \\
5 \\
1 \\
2 \\
1 \\
3\end{array}$ & $\begin{array}{l}0 \\
2 \\
0 \\
0 \\
2 \\
0 \\
3 \\
1 \\
3 \\
6 \\
0 \\
0\end{array}$ & $\begin{array}{r}0 \\
2 \\
2 \\
4 \\
18 \\
0 \\
0 \\
4 \\
2 \\
2 \\
0 \\
2\end{array}$ & $\begin{array}{l}0 \\
1 \\
0 \\
0 \\
4 \\
1 \\
1 \\
0 \\
2 \\
6 \\
0 \\
0\end{array}$ & $\begin{array}{r}1 \\
11 \\
3 \\
6 \\
28 \\
1 \\
4 \\
10 \\
8 \\
16 \\
1 \\
5\end{array}$ & $\begin{array}{r}0 \cdot 5 \\
6 \cdot 0 \\
1 \cdot 6 \\
3 \cdot 3 \\
15 \cdot 3 \\
0 \cdot 5 \\
2 \cdot 2 \\
5 \cdot 5 \\
4 \cdot 4 \\
8 \cdot 7 \\
0 \cdot 5 \\
2 \cdot 7\end{array}$ \\
\hline Total & . & 26 & 17 & 36 & 15 & 94 & $51 \cdot 2$ \\
\hline $\begin{array}{l}\text { Surgeons } \\
\text { Ear-nose-throat } \\
\text { General surgeon } \\
\text { Genito-urologist } \\
\text { Gynaecologist } \\
\text { Ophthalmologist } \\
\text { Orthopaedist }\end{array}$ & $\begin{array}{l}\ldots \\
\cdots \\
\cdots \\
\cdots\end{array}$ & $\begin{array}{l}9 \\
0 \\
4 \\
1 \\
2\end{array}$ & $\begin{array}{l}1 \\
2 \\
3 \\
0 \\
1\end{array}$ & $\begin{array}{r}7 \\
15 \\
5 \\
19 \\
5 \\
3\end{array}$ & $\begin{array}{l}1 \\
4 \\
1 \\
4 \\
0 \\
2\end{array}$ & $\begin{array}{r}18 \\
21 \\
13 \\
23 \\
6 \\
8\end{array}$ & $\begin{array}{r}9.9 \\
11 \cdot 5 \\
7 \cdot 1 \\
12.6 \\
3 \cdot 3 \\
4 \cdot 4\end{array}$ \\
\hline Total & .. & 16 & 7 & 54 & 12 & 89 & $48 \cdot 8$ \\
\hline
\end{tabular}

method which I think is of the utmost value to all concerned. It permits a proper consultation to take place between the family doctor and the consultant ; the patient is often saved a long wait for an out-patient appointment, or indeed he may avoid being admitted to hospital ; the family have the opportunity of seeing the specialist, and are able to ask their questions ; finally, the consultant gains by seeing the patient in his own home environment-a sick person among his family in his own home, and not a patient in hospital.

\section{Domiciliary Consultations}

Analysis of the 80 domiciliary consultations is shown in Table XII. There is here a majority of females, due mostly to the number seen by a psychiatrist. Perhaps in this branch

TABLE XII.-Analysis of 80 Domiciliary Consultations

\begin{tabular}{|c|c|c|c|c|c|}
\hline & & Male & Female & Total & $\%$ \\
\hline 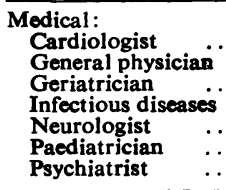 & $\begin{array}{l}\ldots \\
\cdots \\
\cdots \\
\cdots \\
\cdots\end{array}$ & $\begin{array}{l}2 \\
2 \\
0 \\
3 \\
1 \\
3 \\
6\end{array}$ & $\begin{array}{r}1 \\
4 \\
1 \\
1 \\
0 \\
2 \\
20\end{array}$ & $\begin{array}{r}3 \\
6 \\
1 \\
4 \\
1 \\
5 \\
26\end{array}$ & $\begin{array}{r}3.7 \\
7.5 \\
1.2 \\
5.0 \\
1.2 \\
6.2 \\
32.5\end{array}$ \\
\hline Total & .. & 17 & 29 & 46 & 57.3 \\
\hline $\begin{array}{l}\text { Surgical: } \\
\text { Ear-nose-throat ... } \\
\text { General surgeon ... } \\
\text { Genito-urologist .. } \\
\text { Gynaecologist } \ldots \\
\text { Orthopaedist } \ldots\end{array}$ & $\begin{array}{l}\ldots \\
\ldots \\
\cdots \\
\ldots\end{array}$ & $\begin{array}{l}\frac{1}{2} \\
3 \\
8\end{array}$ & $\begin{array}{r}1 \\
4 \\
1 \\
4 \\
10\end{array}$ & $\begin{array}{r}2 \\
6 \\
4 \\
4 \\
18\end{array}$ & $\begin{array}{r}2.6 \\
7.5 \\
5.0 \\
5.0 \\
22.6\end{array}$ \\
\hline Total & .. & 14 & 20 & 34 & $42 \cdot 7$ \\
\hline
\end{tabular}

of medicine more than in any other is the domiciliary consultation of value. So often the patient cannot be persuaded to go to hospital to see a psychiatrist, but he can be helped by the psychiatrist coming to see him. Again, there is the advantage of the psychiatrist seeing the patient in his normal environment, and also of being able to discuss the case with the family.

Apart from the 26 referrals by domiciliary consultation with a psychiatric consultant, 34 other patients were referred to psychiatrists, some of them more than once each. Table XIII shows the diagnosis in the 60 patients referred to psychiatrists, the majority of them being for severe psychoneuroses and psychoses. The small number admitted is to the credit of the consultants concerned, as out-patient treatment was arranged for many cases in spite of the difficulty in getting a patient adequate psychotherapy under the National Health Service. Because of this I have taken on a 
Table XIII.-Analysis of 60 Patients Referred to Psychiatrists During 1951-3

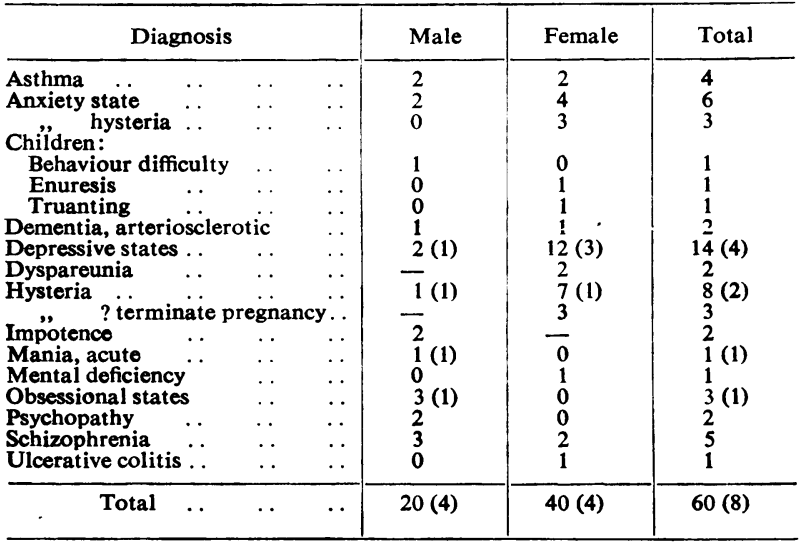

Figures in parentheses denote immediate admissions as in-patients.

much larger number of patients for psychotherapy than 1 referred, and I have discovered that in fact, contrary to the opinion of some psychiatrists, the family doctor is exceptionally well placed to treat patients by this method. Not only does he know his patient's home background, he already has the trust and confidence that is so necessary if psychotherapeutic methods are to succeed. Even those patients who say they do not "believe" in psychology can be treated without their even realizing it-and later, when they come to see how they have responded to this type of approach, their gain in insight is often remarkable.

The largest group of patients seen on domiciliary visits by the surgical consultants was the orthopaedic one ; mostly the referral was for a patient with severe acute back pain, the most frequent cause being a disk lesion. Occasionally a plaster-of-Paris jacket helps the patient get about ; more often, however, it is useful as a means of setting the wheels in motion for routine $x$-ray examination of the back in order to estimate the extent of spondylosis - and to exclude any other possible pathological condition. Also, arrangements can be made for suitable physiotherapy to be started at the optimum time during the period of recovery. In this way the delay (which may be as long as four to six weeks) in waiting for an out-patient appointment is avoided.

Table XIV shows the numbers of referrals according to sex, and whether for medical or surgical conditions, for the four main reasons for referring patients to hospital. It will

TABLE XIV.-Numbers of Referrals According to Sex, and whether for Medical or Surgical Conditions, for each of the Four Main Reasons for Referring them

\begin{tabular}{|c|c|c|c|c|c|c|}
\hline \multirow{2}{*}{$\begin{array}{l}\text { Reason for } \\
\text { Referral }\end{array}$} & \multicolumn{2}{|c|}{ Male } & \multicolumn{2}{|c|}{ Female } & \multirow{2}{*}{ Total } & \multirow{2}{*}{$\%$} \\
\hline & Medical & Surgical & Medical & Surgical & & \\
\hline $\begin{array}{l}\text { Treatment } \\
\text { Radiological investiga- }\end{array}$ & 76 & 203 & 92 & 289 & 660 & 53.88 \\
\hline $\begin{array}{l}\text { tion } \\
\text { Pathological investiga- }\end{array}$ & 55 & 82 & 67 & 48 & 252 & 20.57 \\
\hline $\begin{array}{ccc}\text { tion } . & . & . . \\
\text { Opinion } & . & . .\end{array}$ & $\begin{array}{l}38 \\
43\end{array}$ & $\begin{array}{l}12 \\
23\end{array}$ & $\begin{array}{l}66 \\
50\end{array}$ & $\begin{array}{l}14 \\
67\end{array}$ & $\begin{array}{l}130 \\
183\end{array}$ & $\begin{array}{l}10 \cdot 61 \\
14.94\end{array}$ \\
\hline Total & 212 & 320 & 275 & 418 & 1,225 & 100 \\
\hline
\end{tabular}

be seen that just over $50 \%$ are for treatment, usually by some special technique which the general practitioner is not normally expected to do. The ratio of out-patients to inpatients for males is $3.5: 1$, and for female referrals it is $6: 1$. The ratio of surgical:medical referrals is $3: 2$ for males, and nearly $2: 1$ for females.

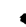

\section{Other Reasons for Referral}

There are lesser reasons for referral which may be recognized. One is the doctor's own anxiety to "make sure" no physical disease has been missed. Taylor (1954), in a report of a survey, states: "Claims that as many as a third of the
G.P.'s patients are suffering from neurotic illness appear to have arisen mainly because organic complaints have not been diagnosed." In fact, I have personally always been apprehensive lest this happen in my practice: perhaps this is why my referral rate is so high when compared with others (see Logan, 1953). Nevertheless, in spite of careful physical examination, together with special investigations, the incidence of neurotic illness found among my patients is over $40 \%$ when the generally accepted stress disorders are included (Hopkins, 1955).

A reason commonly claimed for many referrals to hospital is that the patient requested that he be $x$-rayed or that he should see a specialist. In my experience this is a very infrequent reason for referral-provided always that one can give the patient who makes this type of request the necessary time in which to express his fears and anxieties, and to make a thorough clinical examination in order to be certain of the diagnosis before embarking on any form of treatment.

One further reason not yet mentioned is to obtain help in the "disposal" of a patient. I have been fortunate in not having had to do this more than three times, and on each occasion the need for this action was entirely due to the patient being entirely alone in the world, having no family or friends to look after her.

\section{Comment}

In my experience there is quite clearly a simple answer to the first object posed at the beginning of this paper : I believe that the family doctor should play a major part in the care of his patients, and that only when they require treatment not available in general practice should referral to hospital for treatment be made. In the main, this applies to surgical illness. Here, then, is the first part of the answer to the second question set out above-the hospital should provide the staff and facilities for prompt and efficient treatment for those patients in need of it.

The second requirement is for adequate facilities for proper investigation of the patient in the pathological laboratory and in the $x$-ray department-without the patient needing to see any other specialist apart from the pathologist or radiologist. Taylor (1954) provides the answer for those who cry out that this is impossible: "As with pathological open access, it can be argued that radiological open access does not add to the total volume of work done. Indeed, if in a hospital inexperienced house officers are allowed to order $x$-ray films, it can be claimed that the more experienced G.P.s are likely to ask for less on the same patients."

An important point arises here, however, since the general practitioner must be prepared and able to continue treating his patients-so long as the treatment required is within his competence. The all-important factor therefore is time, and it is here that the possibilities for the doctor fall away if he has a large National Health Service list, even if he has ancillary help. Simple mathematics show how much time can be given to each patient when the numbers of patients and the available time are known.

Finally, the hospital's functions must include consultative facilities. Again time is all-important. If the huge numbers of out-patient attendances to consultative clinics for pathological and $x$-ray investigations were reduced, the consultants would more easily be able to see patients by appointmentand this in turn would make it possible for the general practitioner to attend the consultation. This fulfils the meaning of the word, which essentially is a consultation between the family doctor and the consultant-specialist about the patient. This is at present possible on a domiciliary consultation, as described above.

Of course, the hospital has its part to play in furthering the education of the family doctor, and keeping him abreast of modern advances, but this is not the place to discuss that.

Reference has been made to the incidental finding of fresh evidence of the high incidence of psychoneurotic illness and 
stress disorders as a result of this study. It is reasonable to expect that among the number of referrals to hospital would be found the more seriously ill patients, and this was so. Nevertheless, when those who were referred for treatment (excluding the psychiatric referrals) are deducted from the total number of referrals 615 remain. Of these 615 , over one-half-that is, $31.3 \%$ of the total number of referralswere found to be suffering from psychoneurotic illnesses and stress disorders. In the time that has passed since this survey was planned and carried out a careful check has been made and only two patients have been found whose diagnoses were not correct. In both cases, however, referral to hospital had been made and full investigations carried out (in one case a barium-meal examination which was repeated twice, and still reported negative), but the physical disease was missed. It so happened that when, later on, the diagnosis was properly made and treatment completed, it was still obvious that there was serious psychoneurotic illness present. In short, even when physical disease is found there may be no connexion between it and the patient's symptoms, or even when treated for his physical illness the patient still retains those symptoms due to the coexisting psychoneurosis. These findings are at complete variance with Taylor's observation that: "There is a substantial element of truth in the hypothesis that the better the clinician, the less often does he diagnose neurosis."

\section{Conclusions}

In analysing 1,225 referrals to consultants and specialists over a period of three years (1951-3) from a single general practice certain facts emerge. Just over half of the referrals $(53.88 \%)$ were for treatment requiring special techniques not within the general practitioner's competence. Of the remainder, the majority (31.1\%) were for special investigations, in the pathological laboratory or the $x$-ray department. In only $15 \%$ of the referrals was there need for an opinion from a consultant, or advice and guidance for further management of the patient.

Arising from these facts it is possible to emphasize the need for provision of facilities to help the family doctor reach an accurate diagnosis and, where required, to provide consultative out-patient clinics where recommendations for further treatment by the family doctor can be obtained. To burden the hospitals with more than this is to increase the amount of unnecessary work for the staff, and also to deprive the family doctor of his responsibility for and to his patients.

In my experience the incidence of illness due to psychoneurosis and stress disorder is high-over $40 \%$ in my total practice and just over $30 \%$ of all referrals to hospital. This perhaps points to the need for more facilities for the treatment of large numbers of patients by psychotherapeutic methods-both at hospital and by the family doctor.

I would like to take this opportunity to express my grateful thanks for the ever-ready help that I receive from my consultant and specialist colleagues, and also for the co-operation of the many generations of residents at the hospitals I usually use.

\section{REFERENCES}

College of General Practitioners (1955). Third Annual Report, 1955. (Supplement to Practitioner, 175, Dec., 1955.)

Fry, J. (1952). British Medical Journal. 2, 249.

Hopkins, P. (1955). " The General Practitioner and the Psychosomatic Approach," in Modern Trends in Psychosomatic Medicine, edited by D. O'Neill. London.

Hunt, J. H. (1951). Brittsh Medical Journal, 2, 1575.

Hunt, J. H. P. D. (1953). "General Practitioners' Records," General Register Office. Studies on Medical and Population Subjects, No. 7. H.M.S.O., London.

(1954) Practitioner, 173, 188.

Pemberton, J. (1949). British Medical Journal, 1, 306

Taylor, S. (1954). Good General Practicé. London.

\section{NEW ACADEMIC YEAR UNIVERSITY COLLEGE HOSPITAL}

\section{The Doctor's Double Role}

At the opening of the new session of University College Hospital Medical School an address was delivered by Sir ARTHUR FFORDE, headmaster of Rugby School, and the prizes were presented by Lady FForde. Sir Charles HARINGTON, F.R.S., chairman of the school council, who presided, referred in fitting terms to the retirement of the vice-dean, Professor S. J. CowEll, who for sixteen years had been primarily responsible for the selection of students and the instruction of deans in their duties and responsibilities, and also to the retirement of Mr. Alan SHEFFORD, the vice-dean for dental students, who had been at the school since 1913.

The Dean, Dr. J. D. S. Flew, gave a brief account of the school year. During the session the total entry of undergraduate students taking the full course was 92 ; the total number of undergraduate students in attendance was 277 , and of postgraduates 63 .

Sir ARTHUR FFORDE said that no sensible person in these days could possibly be without a lively consciousness of and real gratitude for the enormous advances of medical science and the swift development of medical practice and technique. Nor could one fail to be aware of the degree of self-sacrifice and devotion with which in this country we were blessed in the general practitioner and nursing services. Yet it must be the case that, for anyone in present circumstances who was embarking upon the profession and art of medicine, it was the difficulties and responsibilities and restrictions of the task in its present framework that loomed larger at times than the vast accumulation of knowledge, skill, and prestige which he or she had to rely on at call. It was not so much the endless procession of examinations and the profound and detailed knowledge which it was necessary to acquire in order to pass them, but the sense that, as soon as one was beyond the beaten track and the well-practised techniques, one was holding in one's hand an individual life, and it was assumed by others that one knew precisely what one was doing, even though in one's own heart there was uncertainty. That was likely to be the burden and the challenge, as the discharge of it was truly the glory, of the medical vocation. It was this which distinguished it from all other vocations, with the possible exception of the priesthood.

" How much does it matter, do you think, to me personally as your prospective patient whether you did or did not win a particular prize on a particular occasion or whether you do or do not keep yourself abreast all the time of the latest developments in medical science? You will probably say that it matters a great deal more than you suspect me of thinking. . . . Nevertheless, prize winner or not, if it should turn out that $I$ am later to be your patient, I am more than half inclined to say that the sine qua non of that relationship over and above your knowledge of modern techniques was expressed many centuries ago by Bianor, who indeed wrote in Greek, for that was his language, but who, if he had known English, might have put it something like this, "Behold, I tell you a mystery. This, this nothing, this meanness, this indeed slave, even this man, is loved and is the lord of the soul of another.' I, your patient, am not a thing, but a person, and you must know it and remember it, and make me feel that you do."

Sir Arthur fforde went on to say that in order to maintain this personal relationship, given as must be assumed the best and completest knowledge of the scientific side of medicine, the main difficulty that nowadays one was likely to encounter was what he called the Civil Service difficulty. The doctor had to be part of a large organization, not yet very fully and completely established, in which, in contradistinction to other forms of Civil Service, all the eventual actions were related to particular people rather than to classes of persons. But in relation to this problem he was an optimist. From the point of view of those people who in the past 